\title{
Evaluation of the bioactive compounds of Vernonia amygdalina Delile extracts and their antibacterial potentials on water-related bacteria
}

\author{
Olubukola Olusola-Makinde, Olayinka Bukola Olabanji and Tope Abraham Ibisanmi* (i)
}

\begin{abstract}
Background: This study focused on the evaluation of the bioactive compounds of Vernonia amygdalina Del. leaf extracts and their antibacterial potential on some water-related bacterial isolates. The bacterial isolates were confirmed using standard microbiological test. The leaves of $V$. amygdalina were subjected to extraction using the Maceration method with water and ethanol as the extraction solvents. Gas chromatography-mass spectroscopy (GC-MS) was carried out on extracts. Antibacterial susceptibility test of $\mathrm{V}$. amygdalina extracts on isolates was carried out.

Results: Aqueous extract of $V$. amygdalina had a higher percentage yield (11.89\%) than the ethanol extract (5.37\%). The GC-MS carried out revealed the presence of butanoic acid, squalene, palmitaldehyde, octadecanoic acid, Z-hexadecanoic acid ethyl ester, oxirane, tetradecyl, 3- methyl-2-phenylindole, n-heneicosane, phytol, methyl-2-O-benzyld-arabinofuranoside, cholest-5-en-3-ol acetate; with hexadecanoic acid ethyl ester and 1,1-diethoxy-3methylbutane having the highest percentage composition of $24.37 \%$ and $13.42 \%$ in aqueous and ethanol extract, respectively, aqueous extract highly inhibited Escherichia coli with an inhibition zone of $10.333 \pm 0.882$ and $36.667 \pm 0.882$ for 25 mg/ $\mathrm{ml}$ and $100 \mathrm{mg} / \mathrm{ml}$, respectively, while the ethanol extracts inhibited most of the isolates with an inhibition range of $7.000 \pm 1.155$ to $30.333 \pm 0.882$. The minimum inhibitory concentration for both extracts on the isolates varies from 25 to $50 \mathrm{mg} / \mathrm{ml}$.
\end{abstract}

Conclusions: The ethanol extract of $V$. amygdalina had a higher inhibitory activity on the bacterial isolates than water. These findings indicate the potential of ethanol extract of $V$. amygdalina leaf in the treatment of water borne infections.

Keywords: Bacteria, Vernonia amygdalina, Antibacterial, Surface water

\section{Background}

Surface water refers to water on the surface of the planet occurring in lakes, rivers, streams, or other freshwater sources used for drinking water supplies. Lakes, rivers and streams have important multi usage components, such as sources of drinking water, irrigation, fishery

*Correspondence: topeibisanmi@gmail.com

Department of Microbiology, School of Sciences, Federal University of Technology, P.M.B. 604, Akure, Ondo state, Nigeria and energy production (Bwire et al. 2020). Water is certainly the source of life, but has the potential to harbour pathogens that can cause serious harm to the human body, proper care must be taken in determining when it is safe to drink and when it isn't. An outbreak of waterborne disease is usually described as an event meeting two criteria: (a) at least two people have experienced similar illness after exposure to the same water source; and (b) epidemiological evidence that implicates water as the probable source of the illness (Jenkins et al. 2021). The outbreaks of waterborne diseases are not limited to 
developing countries; affluent countries are also affected (WHO 2019).

The increase in the outbreaks of waterborne diseases occurs where standard of water, sanitation and personal hygiene are low. Worldwide, the proportion of people with access to portable drinking water and basic sanitation rose from $78 \%$ in 1990 to $83 \%$ in 2004 . However, an estimated 425 million children under 18 years of age still have no access to a standard water supply. It was estimated that diarrhoea due to unsafe water and a lack of basic sanitation contributes to the death of 1.5 million children who are less than five years of age each year, in 2004. Most of these deaths occur in lowand middle-income Countries, the factors related to higher prevalence of diarrhoea among this children are lack of education of mother, breastfeeding for less than 1 year, lack of exclusive breastfeeding, literacy, personal hygiene, roundworm infestation, night blindness, female sex, overcrowding, garbage disposal, nutritional status, immunization status, source of water supply and toilet facility (Gupta et al. 2015).

In the European Region, the annual burden of diarrhoeal disease attributable to poor water quality, sanitation and hygiene in children aged $0-14$ years is estimated at 13,548 deaths ( $5.3 \%$ of all deaths) and 31.5 disabilityadjusted life years (DALYs) per 10,000 children (WHO 2004).

This is a regular cause of diseases such as cholera, typhoid, viral hepatitis A and dysentery. Water can be contaminated with naturally occurring inorganic elements such as arsenic, radon or fluoride. Human activities may also cause water to become contaminated with substances such as lead, nitrates and pesticides (WHO 2019).

In addition to the potential risks posed by poor-quality drinking water, polluted bathing water can cause serious and potentially lethal diseases. These include severe diseases such as typhoid and leptospirosis, as well as a number of minor infections. Health risks are highest among people with compromised/suppressed immune systems or among specific risk groups, such as tourists who do not have immunity against locally endemic diseases (Okpasuo et al. 2020). Presently, the general quality of bathing water in Europe, as indicated by the presence of coliforms and pathogens in bathing waters, poses limited health risks. The quality has improved since the 1990s: in $2007,95 \%$ of the monitored coastal bathing waters and $89 \%$ of inland bathing waters complied with the mandatory standards. Nevertheless, a high level of compliance with mandatory standards (such as the occurrence of indicator bacteria) does not necessarily mean there are no factors that could potentially affect public health (Corpuz et al. 2020).
The use of medicinal plants is continually increasing worldwide. The increasing search for therapeutic agents derived from plant species is justified by the emergence of resistant diseases and the increase in the scientific knowledge of the herbal medicines as important treatment alternatives (Vaou et al. 2021). There has been a great deal of interest recently in the role of complementary and alternative medicines for the treatment of various acute and chronic diseases. Of the various classes of phytochemicals, interest has focused on the anti-inflammatory and antioxidant properties of polyphenols found in various botanical agents (Gashe and Zeleke 2017). Plant's vegetables and spices used in folk and traditional medicine have gained a wide recognition as one of the main sources of prophylactic and chemo-preventive drug discovery and development. Indeed, fruits and plants are rich sources of phenolic compounds and have been recognized to possess a wide range of properties including antioxidant, antibacterial, anti-inflammatory, hepato-protective and anti-carcinogenic actions. Many of the biological functions of flavonoids and phenolic compounds have been attributed to their free radical scavenging, metal ion chelating and antioxidant activities. Antioxidant phenolic agents have been implicated in the mechanisms of chemoprevention which refers to the use chemical substances of natural origin or synthetic to reverse, retard or delay the multistage carcinogenesis process (Gashe and Zeleke 2017).

Vernonia amygdalina, commonly known as "bitter leaf", is a shrub that grows up to $3 \mathrm{~m}$ high in tropical African and other parts of Africa, particularly, Nigeria, Cameroon and Zimbabwe. It is reputed to have several health benefits. The organic fraction extracts of the plant were shown to possess cytotoxic effects towards human carcinoma cells of the nasopharynx. It is effective against amoebic dysentery and gastrointestinal disorders and has antimicrobial and anti-parasitic activities (Etim et al. 2012).

\section{Methods}

\section{Materials used and sterilization of glass wares}

The materials used were funnels, Whatman No. 1 filter paper, measuring cylinder, plain bottles, paper tape, mulin cloth, beaker, conical flask, foil paper, cotton wool, syringes, test tubes, test tube rack, petri dishes, inoculating loop, cork borer $(6 \mathrm{~mm})$, swab stick, gloves, bijou bottles, bowl, marker and membrane filter. All glasswares were sterilized for $40-60 \mathrm{~min}$ at $160^{\circ} \mathrm{C}$ in a hot air oven.

Solvents used $90 \%$ ethanol and distilled water.

Diluent used dimethyl sulphur oxide (DMSO) and distilled water. 
Equipment used electric blender, autoclave, incubators, refrigerator, rotary evaporator, weighing balance and spectrophotometer.

\section{Collection of bacterial cultures and identification}

The bacterial isolates used in this study were obtained from the Department of Microbiology at the Federal University of Technology. These isolates were previously isolated from surface water samples in Akure, Ondo State, Nigeria, and they include Escherichia coli, Bacillus substiles, Staphylococcus aureus, Streptococcus pyrogens, Corynebacterium sp. Enterococcus faecalis and Pseudomonas aeruginosa.

\section{Collection and extraction of plant material}

The Vernonia amygdalina leaf was collected in a farm settlement at Apatapiti, FUTA south gate, Akure, Ondo State. They leaves were authenticated at the department of Crop, Soil and Pest management in Federal University of Technology, Akure. Using the air-drying method, the leaves were air-dried for about three weeks and pulverized using an electric blender (Marlex Electrolyne IS: 250). 100\% ethanol and cold water were used as the solvent for extraction. $453.5 \mathrm{~g}$ of the pulverized bitter leaf was soaked in $2250 \mathrm{ml}$ (2.25 l) of ethanol. $453.5 \mathrm{~g}$ of homogenized Vernonia amygdalina was dissolved in $3500 \mathrm{ml}$ (3.5 l) of cold water. The solutions was allowed to left for $72 \mathrm{~h}$ for proper extraction to occur. Using a muslin cloth or cheese cloth and filtered using No 1 Whatman filter paper, each of the solution were sieved; one after the other. The sieved solutions were collected in a beaker and concentrated in vacuo using rotary evaporator for solvent evaporation. The weight of the dried extracts was measured, and the percentage extract recovery was calculated.
Staphylococcus, Streptococcus, Bacillus. Gram-negative bacteria stain red or pink, which is the colour of the counter stain (safranin) (Leboffe and Michael 2014).

\section{Biochemical characterization of bacterial isolates}

This was done to give more definite and distinguishing characteristics of the isolates. The bacterial isolates were confirmed by subjecting them to biochemical characterizations. The tests include Gram staining, indole, catalase, motility, oxidase, coagulase test, urease test, sugar fermentation test and spore staining test.

\section{Oxidase test}

A flamed inoculating loop was used to pick a colony of freshly grown organism 18-24-h-old growth on a culture plate. A smear was then made on a filter paper and moistened with the oxidase reagent (2-3 drops of $1 \%$ tetra methyl-p-phenylenediaminedihydrochloride, (Kovac's formulation) or dimethy-p-phenylenediaminedihydrochloride (Gordon and McLeod's reagent). A colour change of blue was observed at the site of inoculation within 10-30 s which indicates a positive result. Pseudomonas is oxidase positive (Fawole and Oso 2001).

\section{Motility test}

This was done to know whether the organism is able to move from one place to another. A 24-h old broth of the isolate was placed on a cover slip and covered with the corner of the cover slip; the slide was inverted immediately and was examined under high power and oil immersion lenses (Fawole and Oso 2001).

\section{Coagulase test}

This was done to know the organism that have coagulase

$$
\text { Percentage Extract Recovered }=\frac{\text { dry weight of extract recovered after extraction }}{\text { initial dry weight of plant part }} \times 100 \%
$$

\section{Colonial, morphological and biochemical characterization of bacterial isolates \\ Colonial characterization of bacterial isolates}

The bacterial isolates were plated on suitable agar plates and were incubated for $18-24 \mathrm{~h}$ at $37{ }^{\circ} \mathrm{C}$, and the growths on the plates were observed for their colonial characteristics.

\section{Morphological characteristics of bacterial isolates}

Using the Gram staining technique, the morphological characteristics of the cell wall of the isolates were observed. Gram-positive bacteria retained the colour of the primary stain which is purple. Examples of Grampositive bacteria are species of Bacillus, Clostridium, enzyme. The slide was marked into two sections after which a loop of normal saline $(0.85 \%) \mathrm{NaCl}$ in aqueous solution was dropped on the slide; a small amount of the organism (24-h cultured bacteria) was then emulsified in each drop to get a homogenous suspension; a drop of blood plasma was then added to one of the suspensions and stirred for $5 \mathrm{~s}$ after which was then observed after few minutes, clumping near re-emulsified mixture indicated coagulase-positive result (Tortora et al. 2016).

\section{Urease test}

The isolates were cultured in a medium that contains urea and an indicator phenol red. The urease-positive isolates break down urea into ammonia and carbon dioxide. 
Which releases ammonia, the medium becomes alkaline and is indicated by the change of colour of the medium to pink or red. Urease gradient was prepared in a bijou bottle. The test organism was inoculated into the urease slope and incubate for $24 \mathrm{~h}$ at $37^{\circ} \mathrm{C}$. Colour change was observed. Colour change to pink-red is an indication that the test organism is urease positive (Winn et al. 2006).

\section{Catalase test}

On a grease free slide, a drop of hydrogen peroxide was added using dropping pipette. With the aid of an applicator stick, a pure colony of the organism was picked from the cultured plate and drop on the hydrogen peroxide. A production of effervescence was observed which is characterized by the production of bubbles, indicating that the organism is catalase positive. However, the absence of bubbles of gas signifies a catalase-negative test organism (Fawole and Oso 2001).

\section{Indole test}

The test organism was inoculated into peptone water and incubated at $35-37{ }^{\circ} \mathrm{C}$ for $24 \mathrm{~h}$. After incubation, few drops of the broth culture into a test tube. About two drops of Kovac's reagent was added and shaken. The appearance of red ring at the uttermost layer indicates that the organism is indole positive (Fawole and Oso 2001).

\section{Methyl red test}

This test is used to check for the production of acid by bacterial isolates. The remaining broth from the culture grown for the Voges-Proskauer test is used to perform the methyl red test. A few drops of methyl red solution were added to the culture. An immediate red reaction signifies acid fermentation. A yellow colour is negative (Fawole and Oso 2001).

\section{Sugar fermentation test}

This was done to know the sugars a particular organism can ferment. This test was done by preparing a medium containing $100 \mathrm{ml}$ of nutrient broth and $1 \mathrm{~g}$ fermentable sugars such as glucose, sucrose, galactose, maltose and lactose after which $0.02 \mathrm{~g}$ of phenol red was then added as an indicator. Eight millilitres $(8 \mathrm{ml})$ from each of this sugar solution was transferred into 5 test tubes each with Durham tubes in inverted form making sure that bubbles are not present in the Durham tubes. It was then sterilized in an autoclave at $121{ }^{\circ} \mathrm{C}$ for $15 \mathrm{~min}$. After sterilization, each tube containing the sugars was inoculated with one organism and was incubated at optimum temperature of $25^{\circ} \mathrm{C}$ for 3 days, acid production was observed by a change in colour from red to yellow and this indicated the utilization of the sugar by the isolate resulting in the production of acid; gas production by the organism was indicated by gas in the Durham's tube (Fawole and Oso 2001).

Gas chromatography-mass spectroscopy (GC-MS) analysis Using a gas chromatography-mass spectrometry analysis, the chemical components and their percentage of abundance in the extracts were evaluated. The extracts were analysed using a Varian GC-MS equipment (Varian 4000 mass spectrometer, USA) together with a mass spectrometer (MS) 3800 and equipped with Agilent MS capillary column $(30 \mathrm{~m} \times 0.25 \mathrm{~mm}$, i.e., film thickness) The conditions for the analysis operation were as follows: a starting temperature of $35^{\circ} \mathrm{C}$ which was steadily raised to $95{ }^{\circ} \mathrm{C}$ at a rate of $3{ }^{\circ} \mathrm{C} / \mathrm{min}$ for $10 \mathrm{~min}$, it was increased to $270{ }^{\circ} \mathrm{C}$ at a steady rate of $10{ }^{\circ} \mathrm{C} / \mathrm{min}$ and a final temperature of $300{ }^{\circ} \mathrm{C}$ at a steady rate of $3{ }^{\circ} \mathrm{C} / \mathrm{min}$ that was maintained for $3 \mathrm{~min}$; column flow rate of $0.8 \mathrm{~mL} / \mathrm{min}$; carrier helium at a flow rate of $1.0 \mathrm{~mL} / \mathrm{min}$; split ratio 10:1; the ionization voltage of $70 \mathrm{eV}$; run time $67.5 \mathrm{~min}$; and sample injection volume was $1 \mu \mathrm{L}$ solution of extract ( $5 \mathrm{mg} / \mathrm{mL}$ ). The components were identified by comparing the obtained spectra with those on the NIST 05a library database, and the percentages of abundance were determined with the total ion chromatogram. $1 \mathrm{~mL}$ sample was prepared by diluting the extract with analytical absolute ethanol at a ratio of 1:20 (w/v). The sample and replicate were continuously injected as one batch in random order to discriminate technical from biological variations. Additionally, the prepared pooled samples were used as quality controls (QCs), which were injected at regular intervals throughout the analytical run to provide a set of data from which the repeatability can be assessed.

\section{Sterility proofing of extracts}

The sterility proofing of the extracts was done by introducing $2 \mathrm{ml}$ of the extract into $10 \mathrm{ml}$ of Muller Hinton broth and incubated at $37{ }^{\circ} \mathrm{C}$ for $24 \mathrm{~h}$. The absence of turbidity or clearness of the broth after the period of incubation signifies the presence of a sterile extract.

\section{Reconstitution of extracts}

The different concentrations of the extract (i.e., $25 \mathrm{mg}$, $50 \mathrm{mg}$ and $100 \mathrm{mg}$ ) to be used were weighed and dissolved in $1 \mathrm{ml}$ of diluted DMSO (dimethylsulphoxide) and a membrane filter was used to sieve out any contaminants in the extract.

\section{Antibacterial testing of bacterial isolates}

Antibacterial activities of the plant extracts were determined using the agar well diffusion method. Different concentrations of $25 \mathrm{mg} / \mathrm{ml}, 50 \mathrm{mg} / \mathrm{ml}, 100 \mathrm{mg} /$ $\mathrm{ml}$ of the extracts were used for the bioassay. After 
incubation, zones of inhibition formed in the medium were measured in millimetre $(\mathrm{mm})$ diameter. Ciprofloxacin $(0.15 \mathrm{~g} / \mathrm{ml})$ was used as standard antibacterial agent for positive control. Using Mueller Hinton agar, $15.2 \mathrm{~g}$ of the agar was measured and dissolved in $400 \mathrm{ml}$ of water (prepared according to manufacturer's specification) in conical flask which was shaken to homogenize the mixture. The mixture was cocked and labelled appropriately and autoclaved at $121{ }^{\circ} \mathrm{C}$ for $15 \mathrm{~min}$. After autoclaving, the media was brought out and allowed to cool; on a sterile work bench, petri dishes were arranged and the cooled media was poured into the dishes $(10 \mathrm{ml}$ per plate) under aseptic condition. After pour plating, the media was allowed to solidify. Using a swab stick, an already prepared $18-24$ h nutrient broth of the organisms was swabbed across the agar plate and labelled accordingly. The swabbed plates were left for $15 \mathrm{~min}$ before boring holes in it (about $3-4$ holes per plate) using a sterile cock borer $(6 \mathrm{~mm})$ and the wells were labelled according to the concentrations of the extracts to be used. The extracts (of different concentrations) and the controls were introduced into the wells until they were full using a sterile syringe to which a membrane filter was attached to and the plates were incubated afterwards at $37^{\circ} \mathrm{C}$ for $24 \mathrm{~h}$ and zones of inhibition were checked for and measured and recorded.

\section{Determination of minimum inhibitory concentration of leaf extracts of $V$. amygdalina}

The MIC of isolates was carried out using tube dilution technique. McFarland turbidiometric standard $\left(10^{6} \mathrm{cfu} / \mathrm{ml}\right)$ was used to standardize the concentration of test coliforms. A tube containing $9 \mathrm{ml}$ of nutrient broth was seeded with $0.9 \mathrm{ml}$ of the extract with a loopful of the test organism previously diluted to 0.5 McFarland turbidiometric standard. After incubation for $24 \mathrm{~h}$ at $37{ }^{\circ} \mathrm{C}$, the tubes were then examined for microbial growth by observing the turbidity with a spectrophotometer.

\section{Data analysis}

Data obtained were subjected to Analysis of Variance (ANOVA) using Statistical Package for Social Science (SPSS) version 17.0, and means were separated according to Duncan's Multiple Range Test (DMRT) at 5\% probability level.

\section{Results \\ Colonial and morphology of bacterial isolates}

The colonial and morphological view of the isolates compliments the biochemical tests which are known in Table 1. The morphological view of the isolates is based on the physical appearance of the isolates on an agar plate; it identifies the colony shape, size, texture, colour and elevation of the isolates when plated on a suitable agar medium. The microscopic view of the isolates identifies the cell shape, their reaction to Gram staining (either positive or negative in response to the presence or absence of peptidoglycan) and the arrangement of the cell (singly or in pairs, in chains or in clusters). $75 \%$ of the bacterial isolates are Gram negative, while $25 \%$ are Gram positive; all the bacteria isolates have smooth texture, $50 \%$ of the isolates are rod-shaped bacteria, while the remaining $50 \%$ are cocci-shaped bacteria; each isolate has their own distinctive morphological colour; and only three of the isolates are cream colour. Majority of the isolates have slightly raised to raise elevation; only Bacillus subtilis has a flat elevation, while Enterococcus faecalis has a convex elevation. Bacillus subtilis appeared to be a Gram-positive rods, with big colonies which are arranged singly or in pairs, having a flat elevation with a smooth texture and a cream colouration. Pseudomonas aeruginosa appeared to be a Gram-negative rods, with big colonies which are arranged singly, having a raised elevation with a smooth texture and a green colouration.

Table 1 Microscopic and morphology of bacterial isolates

\begin{tabular}{|c|c|c|c|c|c|c|c|}
\hline Probable organism & G.R & Shape & Size & Arrangement & Elevation & Texture & Colour \\
\hline Bacillus subtilis & + & Rod & Big & Singly or pairs & Flat & Smooth & Cream \\
\hline Corynebacterium diphtheriae & + & Rod & Small & Straight and slightly curved & Raised & Smooth & Metachromatic \\
\hline Enterococcus faecalis & + & Cocci & Small & Short chains, in pairs & Convex & Smooth & Grey \\
\hline Escherichia coli & - & Rod & Big & Singly or in pairs & Raised & Smooth & Metallic sheen \\
\hline Pseudomonas aeruginosa & - & Rod & Big & Singly & Raised & Smooth & Green \\
\hline Staphylococcus sp. & + & Cocci & Large & Clusters & Slightly raised & Smooth & Cream \\
\hline Staphylococcus aureus & + & Cocci & Large & Clusters & Slightly raised & Smooth, shinny & Golden-yellow \\
\hline Streptococcus pyogenes & + & Cocci & Tiny & Chains & Raised & Smooth & Cream \\
\hline
\end{tabular}

Key $\mathrm{G} . \mathrm{R}=$ Gram reaction, $+=$ Positive,$-=$ Negative 


\section{Biochemical reactions of bacterial isolates}

The biochemical reactions of the bacterial isolates give details of the isolates and their reactions to some tests, their ability to utilize some of the components present in the agar or solutions. These tests help to give some distinctive features of the isolates and give a clue on the possible organisms. Corynebacterium diphtheriae was observed to be negative for oxidase, indole, motility, mannitol, sucrose and lactose test and was positive for catalase and glucose. Staphylococcus aureus was observed to be negative for oxidase, indole, motility and mannitol, while it was positive for catalase, glucose, sucrose and lactose test. Bacillus subtilis was observed to be negative for indole and lactose test and was positive for oxidase, motility, catalase, glucose and mannitol test. Enterococcus faecalis was observed to be negative for oxidase, indole, motility and catalase test and was positive to the rest of the test. Pseudomonas aeruginosa was observed to be positive only to oxidase, motility, catalase and mannitol test among the tests carried out. Streptococcus pyogenes was positive only to sucrose, glucose and lactose test. Staphylococcus sp was observed to be positive to indole, catalase, glucose, sucrose and lactose test and was negative for oxidase, motility and mannitol test (Table 2).

\section{Percentage extract yield $V$. amygdalina}

Table 3 shows the amount of available extract yielded after subjecting Vernonia amygdalina leaf to extraction process. The initial dry weight used was $453.5 \mathrm{~g}$ for both solvents and after the extraction process, the dry weight of the aqueous and ethanol extracts is $53.98 \mathrm{~g}$ and $24.36 \mathrm{~g}$, respectively. The percentage extract recovered is $11.89 \%$ and $5.37 \%$ for the aqueous and ethanol extract, respectively.
Table 3 Percentage extract yield Vernonia amygdalina leaf extract

\begin{tabular}{llll}
\hline Extracts & $\begin{array}{l}\text { Initial dry } \\
\text { weight of plant } \\
(\mathbf{g})\end{array}$ & $\begin{array}{l}\text { Dry weight of extract } \\
\text { after evaporation } \mathbf{( g )}\end{array}$ & $\begin{array}{l}\text { Percentage } \\
\text { extract yield } \\
\text { (\%) }\end{array}$ \\
\hline Aqueous & 453.5 & 53.98 & 11.89 \\
Ethanol & 453.5 & 24.36 & 5.37 \\
\hline
\end{tabular}

\section{Bioactive components of aqueous and ethanol extracts of Vernonia amygdalina leaf}

Tables 4 and 5 show the bioactive compounds present in aqueous extract of $V$ amygdalina after GC-MS analysis. It gives details on their peak, retention time (RT) measured in minutes, molecular formulae, their molecular weight (amu) and the percentage abundance of each compounds in the extract. Hexadecanoic acid ethyl ester and 1,1-diethoxy-3methylbutane has the highest percentage abundance of $24.37 \%$ and $13.42 \%$ in aqueous and ethanol extract, respectively. Moreso, Cholest-5-en-3-ol (33)-, acetate and Isoamyl acetate has the least percentage abundance of $0.19 \%$ and $5.59 \%$ in aqueous and ethanol extract of V. amygdalina leaf, respectively (Figs. 1, 2).

\section{Antimicrobial activities of ethanol extract of Vernonia amygdalina leaf}

Tables 6 and 7 represent the zones of inhibition gotten when ethanol extracts was tested against the bacterial isolates. All determinations were conducted in triplicate, and the data are expressed as mean \pm standard error (SE). Values with the same superscript were considered significantly different at $p<0.05$. The antibacterial activity of $V$. amygdalina leaf extracts against the tested isolates had varying inhibition zones at varying concentration; aqueous extract highly inhibited Escherichia coli with an inhibition zone of $10.333 \pm 0.882$ and $26.667 \pm 0.882$ for $25 \mathrm{mg} / \mathrm{ml}$ and $100 \mathrm{mg} / \mathrm{ml}$, respectively, while the ethanol extracts inhibited most of the isolates with an inhibition range of $2.000 \pm 1.155$ to

Table 2 Biochemical reactions of bacterial isolates

\begin{tabular}{|c|c|c|c|c|c|c|c|c|}
\hline Probable organism & Oxidase & Indole & Motility & Catalase & Glucose & Sucrose & Lactose & Mannitol \\
\hline Bacillus subtilis & + & - & + & + & + & + & - & + \\
\hline Corynebacterium diphtheriae & - & - & - & + & + & - & - & - \\
\hline Enterococcus faecalis & - & - & - & - & + & + & + & + \\
\hline Escherichia coli & - & + & + & + & + & - & + & + \\
\hline Pseudomonas aeruginosa & + & - & + & + & - & - & - & + \\
\hline Staphylococcus sp. & - & + & - & + & + & + & + & - \\
\hline Staphylococcus aureus & - & - & - & + & + & + & + & - \\
\hline Streptococcus pyogenes & - & - & - & - & + & + & + & - \\
\hline
\end{tabular}

Key: $+=$ Positive,$-=$ Negative 
Table 4 Bioactive compounds of aqueous extracts of Vernonia amygdalina leaf

\begin{tabular}{|c|c|c|c|c|c|c|}
\hline Peak \# & $\mathrm{RT}$ (mins) & Compounds detected & Mol. for & M.W. (amu) & Peak\% & \%Abundance \\
\hline 1 & 5.174 & Disiloxane, 1,1,3,3-tetramethyl- & $\mathrm{C}_{12} \mathrm{H}_{30} \mathrm{Si}_{2}$ & 134 & 1.32 & 0.48 \\
\hline 2 & 7.544 & Butanoic acid, 2-amino-3-hydroxy, propyl ester & $\mathrm{C}_{7} \mathrm{H}_{15} \mathrm{NO}_{3}$ & 161 & 2.64 & 1.25 \\
\hline 3 & 9.157 & Phenol, 4-(3-hydroxy-1-propenyl)-2-methoxy- & $\mathrm{C}_{10} \mathrm{H}_{12} \mathrm{O}_{3}$ & 180 & 2.96 & 1.80 \\
\hline 4 & 11.448 & Butanoic acid ethyl ester & $\mathrm{C}_{6} \mathrm{H}_{12} \mathrm{O}_{2}$ & 116 & 7.58 & 7.08 \\
\hline 5 & 11.881 & 3-Methyl-2-phenylindole & $\mathrm{C}_{15} \mathrm{H}_{13} \mathrm{~N}$ & 207 & 3.13 & 4.14 \\
\hline 6 & 13.430 & Hexadecanoic acid ethyl ester & $\mathrm{C}_{15} \mathrm{H}_{26} \mathrm{O}$ & 284 & 32.94 & 24.37 \\
\hline 7 & 13.757 & Tetradecanoic acid & $\mathrm{C}_{14} \mathrm{H}_{28} \mathrm{O}_{2}$ & 228 & 6.26 & 12.42 \\
\hline 8 & 13.851 & n-Hexadecanoic acid & $\mathrm{C}_{16} \mathrm{H}_{32} \mathrm{O}_{2}$ & 256 & 6.09 & 8.00 \\
\hline 9 & 15.077 & Oxirane, tetradecyl- & $\mathrm{C}_{16} \mathrm{H}_{32} \mathrm{O}$ & 240 & 2.70 & 0.44 \\
\hline 10 & 15.195 & n-Heneicosane & $\mathrm{C}_{21} \mathrm{H}_{44}$ & 296 & 2.64 & 4.33 \\
\hline 11 & 15.803 & Hexadecanoic acid, methyl ester & $\mathrm{C}_{17} \mathrm{H}_{34} \mathrm{O}_{2}$ & 270 & 2.31 & 4.34 \\
\hline 12 & 17.042 & 9,12,15-Octadecatrienoic acid, (Z,Z,Z)- & $\mathrm{C}_{18} \mathrm{H}_{30} \mathrm{O}_{2}$ & 278 & 0.99 & 2.11 \\
\hline 13 & 19.033 & 9,12,15-Octadecatrien-1-ol, (Z,Z,Z)- & $\mathrm{C}_{18} \mathrm{H}_{32} \mathrm{O}$ & 264 & 1.32 & 2.15 \\
\hline 14 & 20.210 & 9,12-Octadecadienoic acid (Z,Z)- & $\mathrm{C}_{18} \mathrm{H}_{32} \mathrm{O}_{2}$ & 280 & 1.38 & 4.25 \\
\hline 15 & 23.061 & Phytol & $\mathrm{C}_{20} \mathrm{H}_{40} \mathrm{O}$ & 296 & 1.15 & 3.66 \\
\hline 16 & 24.062 & 6-Octadecenoic acid, (Z)- & $\mathrm{C}_{18} \mathrm{H}_{34} \mathrm{O}_{2}$ & 282 & 3.95 & 4.71 \\
\hline 17 & 25.041 & Octadecanoic acid(Stearic acid) & $\mathrm{C}_{18} \mathrm{H}_{36} \mathrm{O}_{2}$ & 284 & 4.02 & 4.22 \\
\hline 18 & 27.626 & Cholest-5-en-3-ol (3ß)-, acetate & $\mathrm{C}_{29} \mathrm{H}_{48} \mathrm{O}_{2}$ & 428 & 3.13 & 0.19 \\
\hline 19 & 29.307 & 1,2 Benzenedicarboxylic acid (Di-n-octyl phthalate) & $\mathrm{C}_{24} \mathrm{H}_{38} \mathrm{O}_{4}$ & 390 & 4.12 & 0.24 \\
\hline 20 & 30.013 & Methyl-2-O-benzyl-d-arabinofuranoside & $\mathrm{C}_{13} \mathrm{H}_{18} \mathrm{O}_{5}$ & 476 & 4.61 & 12.36 \\
\hline 21 & 34.734 & $\beta$-Sitosterol & $\mathrm{C}_{29} \mathrm{H}_{50} \mathrm{O}$ & 414 & 4.78 & 8.09 \\
\hline 22 & & $2,4,7$-Trinitrofluorenone & $\mathrm{C}_{13} \mathrm{H}_{5} \mathrm{~N}_{3} \mathrm{O}$ & 315 & & 2.05 \\
\hline 23 & & Squalene & $\mathrm{C}_{30} \mathrm{H}_{50}$ & 410 & & 6.17 \\
\hline
\end{tabular}

Table 5 Bioactive compounds of ethanol extracts of Vernonia amygdalina leaf

\begin{tabular}{|c|c|c|c|c|c|}
\hline Peak \# & RT (min) & Compound detected & Molecular for & M.W. (amu) & Abundance (\%) \\
\hline 1 & 4.125 & Isoamyl acetate & $\mathrm{C}_{7} \mathrm{H}_{14} \mathrm{O}_{2}$ & 237 & 5.59 \\
\hline 2 & 5.125 & 1,1-diethoxy-3methylbutane & $\mathrm{C}_{9} \mathrm{H}_{20} \mathrm{O}_{2}$ & 290 & 13.42 \\
\hline 3 & 17.325 & $3,7,11,15$ Tetramethyl-2 hexadecen-1-ol & $\mathrm{C}_{20} \mathrm{H}_{40} \mathrm{O}_{2}$ & 283 & 8.86 \\
\hline 4 & 18.975 & Hexadecanoic acid methyl ester & $\mathrm{C}_{17} \mathrm{H}_{34} \mathrm{O}_{2}$ & 252 & 9.63 \\
\hline 5 & 20.367 & Hexadecanoic acid & $\mathrm{C}_{16} \mathrm{H}_{32} \mathrm{O}_{2}$ & 242 & 9.50 \\
\hline 6 & 20.467 & Hexadecanoic acid ethyl ester & $\mathrm{C}_{15} \mathrm{H}_{26} \mathrm{O}$ & 290 & 11.46 \\
\hline 7 & 22.542 & Phytol & $\mathrm{C}_{20} \mathrm{H}_{40} \mathrm{O}$ & 296 & 9.25 \\
\hline 8 & 23.075 & 9,12-Octadecadienoic acid ethyl ester & $\mathrm{C}_{18} \mathrm{H}_{32} \mathrm{O}_{2}$ & 216 & 10.55 \\
\hline 9 & 23.183 & Linoleic acid ethyl ester & $\mathrm{C}_{20} \mathrm{H}_{34} \mathrm{O}_{2}$ & 204 & 10.29 \\
\hline 10 & 25.175 & Eicosanoic acid methyl ester & $\mathrm{C}_{22} \mathrm{H}_{44} \mathrm{O}_{2}$ & 275 & 11.46 \\
\hline 11 & 14.242 & 3, 5-bis 1, 1 dimethyl ethyl (Phenol) & $\mathrm{C}_{10} \mathrm{H}_{12} \mathrm{O}_{3}$ & 206 & 9.15 \\
\hline 12 & 17.808 & Tetradecanoic acid & $\mathrm{C}_{14} \mathrm{H}_{28} \mathrm{O}_{2}$ & 228 & 8.89 \\
\hline 13 & 18.417 & 1, 2-epoxyhexadecane (Oxirane) & $\mathrm{C}_{16} \mathrm{H}_{32} \mathrm{O}$ & 240 & 6.95 \\
\hline 14 & 19.442 & Methyl hexadecanoate (Palmitic acid) & $\mathrm{C}_{17} \mathrm{H}_{34} \mathrm{O}_{2}$ & 270 & 10.16 \\
\hline 15 & 21.800 & 9, 12-octadecadienoic acid (Linoleic acid) & $\mathrm{C}_{18} \mathrm{H}_{32} \mathrm{O}_{2}$ & 294 & 9.32 \\
\hline 16 & 22.133 & 3, 7-dimethyl dodecan-1-ol (Phytol) & $\mathrm{C}_{12} \mathrm{H}_{26} \mathrm{O}$ & 264 & 11.73 \\
\hline 17 & 22.850 & 6-octadecenoic acid (Oleic acid) & $\mathrm{C}_{12} \mathrm{H}_{23} \mathrm{O}_{2}$ & 282 & 10.56 \\
\hline 18 & 23.217 & octadecanoic acid (Stearic acid) & $\mathrm{C}_{18} \mathrm{H}_{36} \mathrm{O}_{2}$ & 284 & 9.16 \\
\hline 19 & 28.117 & Cholest-5, 3-ol, 5-acetate (Cholestane) & $\mathrm{C}_{29} \mathrm{H}_{48} \mathrm{O}_{2}$ & 386 & 8.85 \\
\hline 20 & 28.350 & 1,2-Benzenedicarboxylic acid (Di-n-octyl phthalate) & $\mathrm{C}_{8} \mathrm{H}_{6} \mathrm{O}_{4}$ & 390 & 11.68 \\
\hline
\end{tabular}




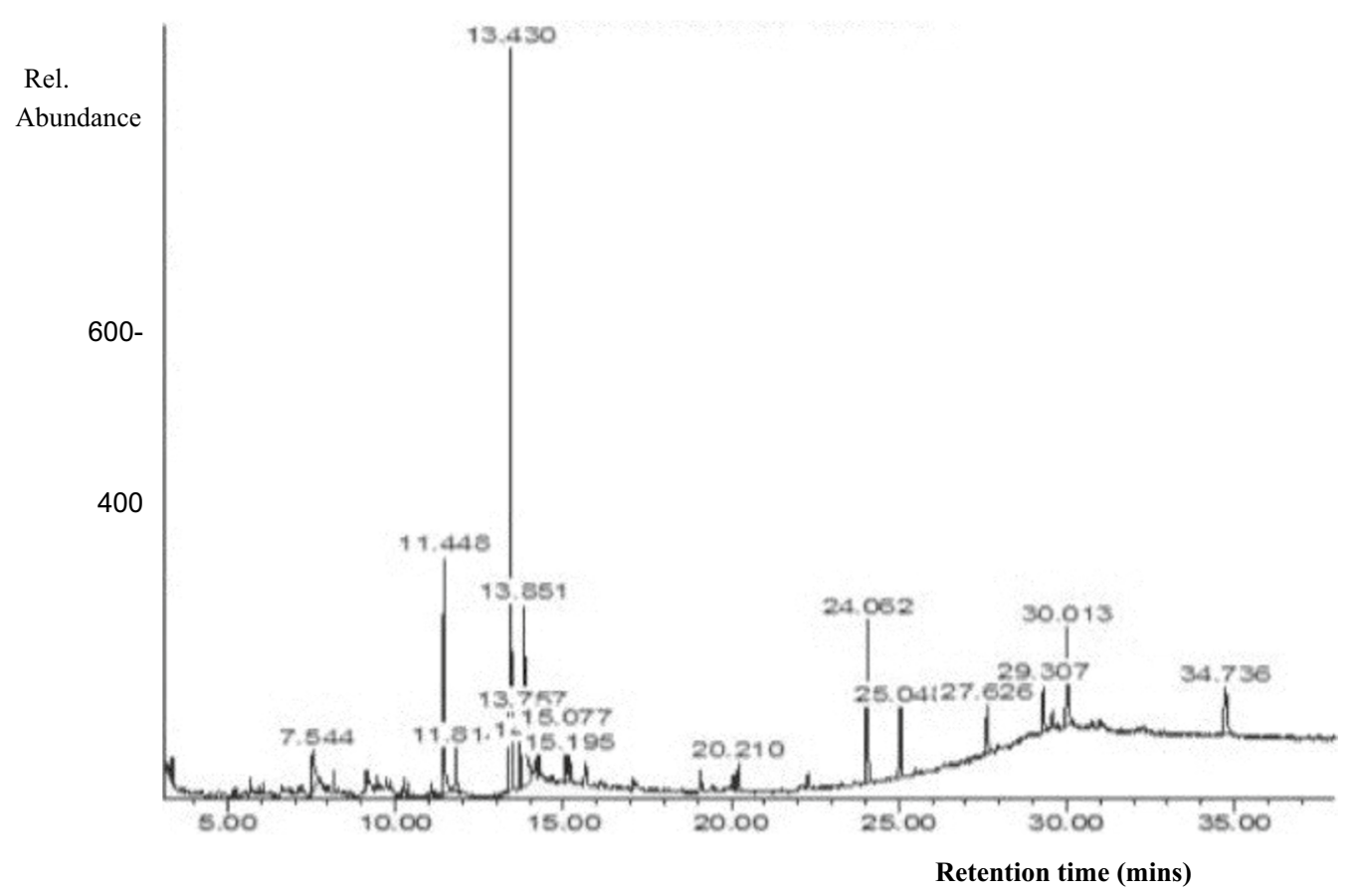

Fig. 1 Bioactive compounds in aqueous extract of Vernonia amygdalina leaf

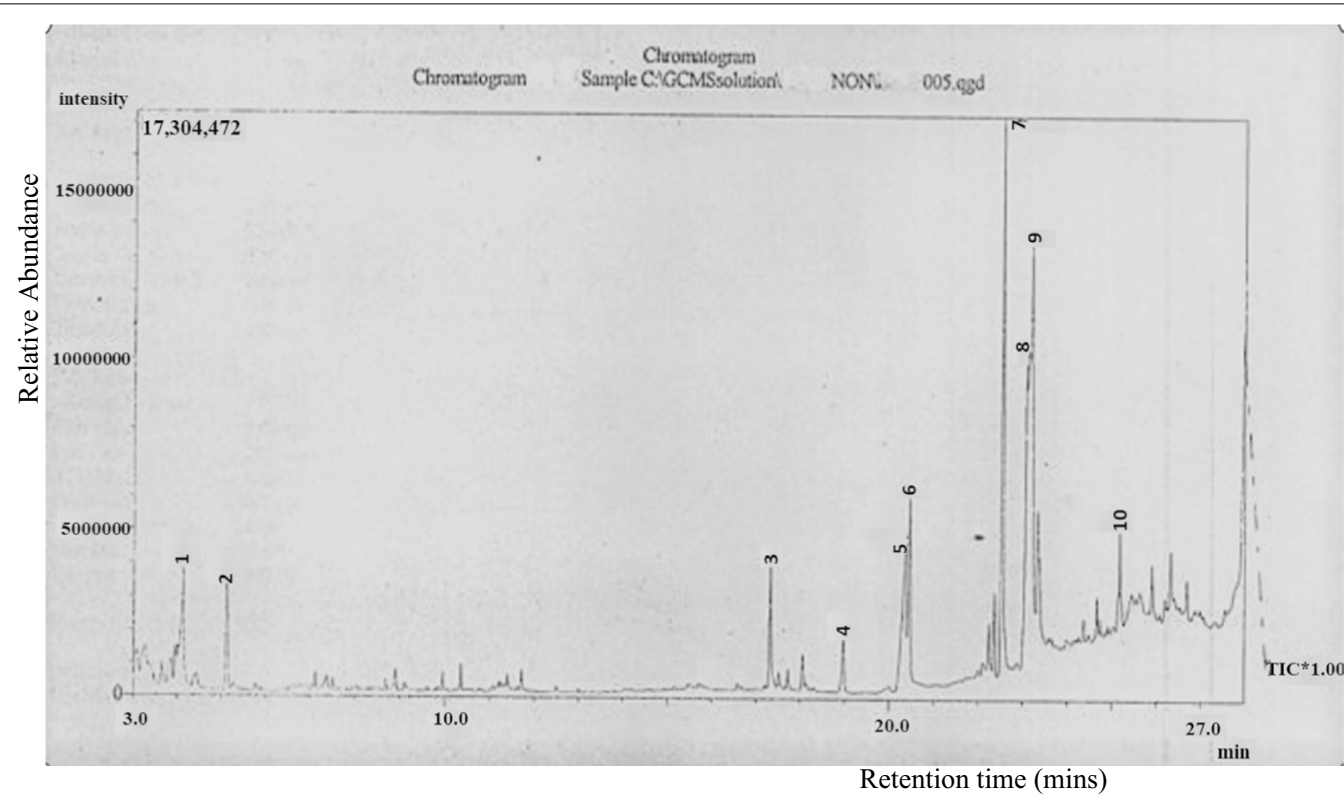

Fig. 2 Bioactive compounds in Ethanol Extract of Vernonia amygdalina

$30.333 \pm 0.882$. Figure 3 shows the antibacterial inhibition of aqueous extract of $V$. amygdalina leaf against Staphylococcus aureus. Figure 4 shows the antibacterial activity of aqueous extract of $V$. amygdalina leaf against Streptococcus pyogenes.
Minimum inhibitory concentration of ethanoic and aqueous extracts of Vernonia amygdalina leaf The table represents the minimum concentration at which the extracts inhibited the bacterial isolates with no isolate strain remaining. The MIC values obtained on 
Table 6 Antimicrobial activities of ethanol extract of Vernonia amygdalina leaf

\begin{tabular}{lccc}
\hline Organisms & $\mathbf{2 5} \mathbf{~ m g / m l}$ & $\mathbf{5 0} \mathbf{~ m g / m l}$ & $\mathbf{1 0 0} \mathbf{~ m g / m l}$ \\
\hline Bacillus subtilis & $4.667 \pm 1.202^{\mathrm{a}}$ & $11.000 \pm 1.000$ & $22.667 \pm 0.882^{\mathrm{c}}$ \\
Corynebacterium diphtheriae & $6.333 \pm 0.333^{\mathrm{a}}$ & $22.000 \pm 0.577^{\mathrm{b}}$ & $30.333 \pm 0.882^{\mathrm{c}}$ \\
Enterococcus faecali & $2.000 \pm 1.155^{\mathrm{a}}$ & $14.333 \pm 0.333^{\mathrm{b}}$ & $29.667 \pm 0.333^{\mathrm{c}}$ \\
Escherichia coli & $8.333 \pm 0.667^{\mathrm{a}}$ & $17.667 \pm 0.882^{\mathrm{b}}$ & $21.000 \pm 0.577^{\mathrm{c}}$ \\
Pseudomonas aeruginosa & $15.333 \pm 1.764^{\mathrm{a}}$ & $22.667 \pm 0.882^{\mathrm{b}}$ & $23.333 \pm 1.453$ \\
Staphylococcus aureus & $4.000 \pm 1.000^{\mathrm{a}}$ & $9.333 \pm 1.202^{\mathrm{b}}$ & $14.333 \pm 1.202^{\mathrm{c}}$ \\
Staphylococcus sp. & $8.667 \pm 2.028^{\mathrm{a}}$ & $13.333 \pm 1.764^{\mathrm{a}}$ & $26.000 \pm 1.000^{\mathrm{b}}$ \\
Streptococcus pyogenes & $7.000 \pm 1.155^{\mathrm{a}}$ & $12.000 \pm 1.155^{\mathrm{a}}$ & $24.667 \pm 3.383$ \\
\hline
\end{tabular}

Mean \pm Standard Error, Superscript $a, b, c=$ significantly different at $p<0.05$

Table 7 Antimicrobial activities of aqueous extract of Vernonia amygdalina leaf

\begin{tabular}{|c|c|c|c|}
\hline Organisms & $25 \mathrm{mg} / \mathrm{ml}$ & $50 \mathrm{mg} / \mathrm{ml}$ & $100 \mathrm{mg} / \mathrm{ml}$ \\
\hline Bacillus subtilis & $1.333 \pm 0.882^{\mathrm{a}}$ & $9.667 \pm 0.882^{b}$ & $17.67 \pm 1.453^{c}$ \\
\hline Corynebacterium diphtheriae & $15.667 \pm 0.882^{a}$ & $24.333 \pm 0.333^{b}$ & $31.667 \pm 0.882^{c}$ \\
\hline Enterococcus faecalis & $2.000 \pm 1.155^{\mathrm{a}}$ & $4.000 \pm 2.646^{\mathrm{a}}$ & $7.333 \pm 1.333^{a}$ \\
\hline Escherichia coli & $10.333 \pm 0.882^{a}$ & $15.667 \pm 1.202^{b}$ & $26.667 \pm 0.882^{c}$ \\
\hline Pseudomonas aeruginosa & $12.333 \pm 0.882^{\mathrm{a}}$ & $16.000 \pm 1.155^{b}$ & $22.333 \pm 0.882^{b}$ \\
\hline Staphylococcus aureus & $1.333 \pm 0.882^{\mathrm{a}}$ & $9.667 \pm 1.453^{b}$ & $21.667 \pm 0.882^{c}$ \\
\hline Staphylococcus sp. & $3.333 \pm 0.882^{\mathrm{a}}$ & $13.667 \pm 0.882^{b}$ & $20.000 \pm 0.577^{b}$ \\
\hline Streptococcus pyogenes & $1.667 \pm 0.882^{\mathrm{a}}$ & $6.333 \pm 0.882^{b}$ & $8.667 \pm 0.882^{b}$ \\
\hline
\end{tabular}

Mean \pm Standard Error Superscript $a, b, c=$ significantly different at $p<0.05$

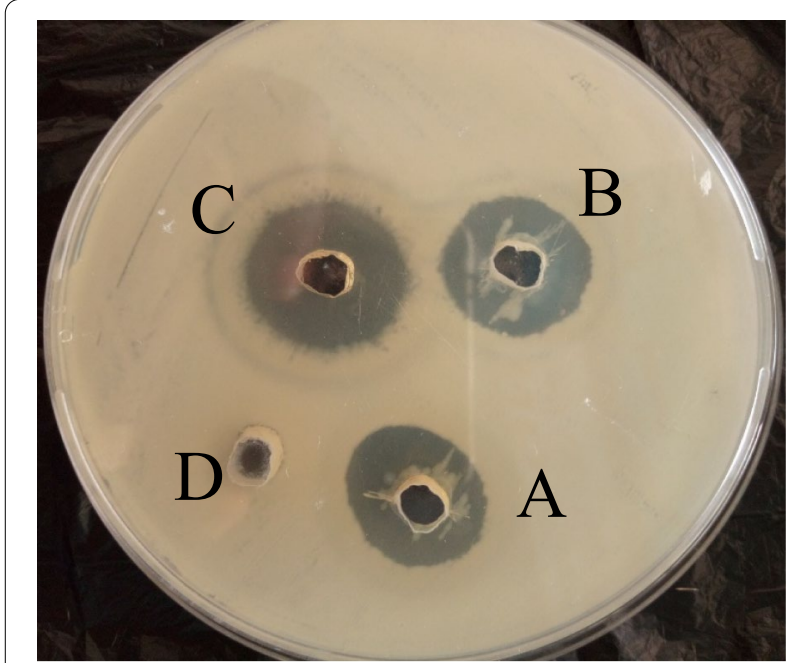

Fig. 3 Antibacterial inhibition of aqueous extract of $V$. amygdalina leaf against Staphylococcus aureus. Keys: $A=25 \mathrm{mg} / \mathrm{ml}, B=50 \mathrm{mg} / \mathrm{ml}$, $\mathrm{C}=100 \mathrm{mg} / \mathrm{ml}, \mathrm{D}=$ negative control. Negative control=DMSO the test organisms varied from one plant extract to the another; the minimum inhibitory concentration for both extracts on the isolates varies from 25 to $50 \mathrm{mg} / \mathrm{ml}$. The ethanol extract of $V$. amygdalina had a higher inhibitory activity on the bacterial isolates than water (Table 8).

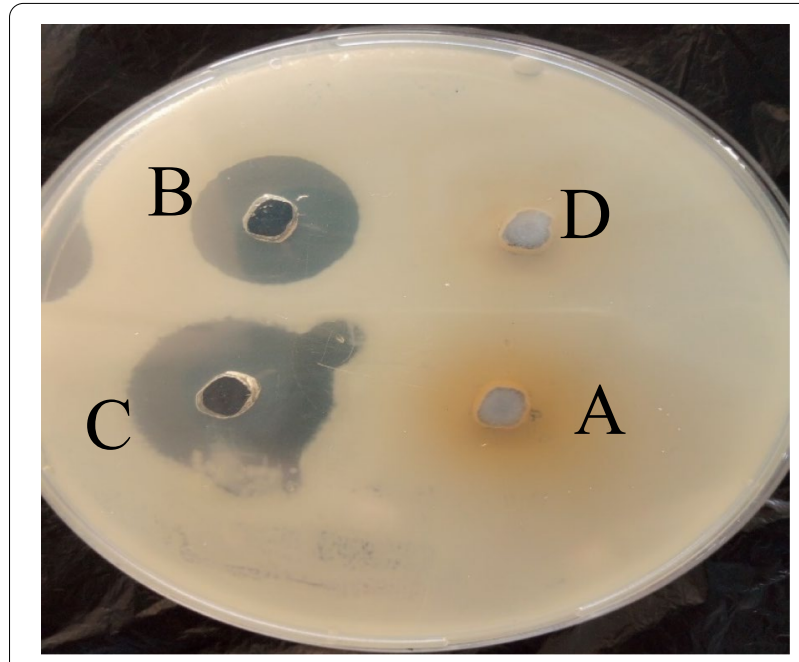

Fig. 4 Antibacterial activity of aqueous extract of $V$. amygdalina leaf against Streptococcus pyogenes. Keys: $A=25 \mathrm{mg} / \mathrm{ml}, B=50 \mathrm{mg} / \mathrm{ml}$, $\mathrm{C}=100 \mathrm{mg} / \mathrm{ml}, \mathrm{D}=$ negative control. Negative control = DMSO

\section{Discussion}

Water-borne diseases due to bacterial infections on surface water have caused an increase in the morbidity and mortality rate of people who are exposed to polluted water; especially those in developing countries (Jenkins 
Table 8 Minimum inhibitory concentration of ethanoic and aqueous extracts of Vernonia amygdalina leaf

\begin{tabular}{llll}
\hline S/N & Organisms & $\begin{array}{l}\text { Ethanol } \mathbf{( m g /} \\
\mathbf{m l})\end{array}$ & $\begin{array}{l}\text { Aqueous } \\
(\mathbf{m g} / \mathbf{m l})\end{array}$ \\
\hline 1 & Bacillus subtilis & 25 & 50 \\
2 & Corynebacterium diphtheriae & 25 & 50 \\
3 & Enterococcus faecalis & 50 & 25 \\
4 & Escherichia coli & 25 & 25 \\
5 & Pseudomonas aeruginosa & 25 & 25 \\
6 & Staphylococcus aureus & 25 & 25 \\
7 & Staphylococcus sp. & 25 & 50 \\
8 & Streptococcus pyogenes & 25 & 50 \\
\hline
\end{tabular}

et al. 2021). The colonial, morphological and biochemical characterization of the bacterial isolates reveals that the isolates were identified to be Escherichia coli, Bacillus subtilis, Staphylococcus aureus, Streptococcus pyogenes, Corynebacterium diphtheriae, Enterococcus faecalis and Pseudomonas aeruginosa. This agrees with Fawole and Oso (2001) who gave an outline on the expected results for some bacterial isolates.

The percentage recovery of $V$. amygdalina extracts showed varying yields even when subjected to the same extraction process with the same amount of dry weight; aqueous extract had a higher percentage recovery of $11.89 \%$ than that of ethanol extract which had a percentage recovery of $5.37 \%$. This agrees with the observation made by Ibekwe et al. (2001) who had similar observation in the extraction of orange peel. This difference may be due to the volatile state of ethanol and the polar state of water.

Green plants are known to represent a reservoir of effective chemotherapeutic agents with more systemic and easily biodegradable potentials. Extract analysis using gas chromatography-mass spectrometry (GCMS) revealed a complex mixture of compounds. Twenty to twenty-three compounds were identified in the aqueous and ethanol extracts of $V$. amygdalina which are mainly characterized by its percentage abundance. Hexadecanoic acid ethyl ester and 1,1-diethoxy3 methylbutane have the highest percentage abundance of $24.37 \%$ and $13.42 \%$ in aqueous and ethanol of $V$. amygdalina leaf extract, respectively, while Cholest-5en-3-ol (3ß)-, acetate and Isoamyl acetate have the least percentage abundance of $0.19 \%$ and $5.59 \%$ in aqueous and ethanol extract of $V$. amygdalina leaf, respectively. This agrees with the study of Rai et al. (2004) who stated that terpenoids constitute a group of compounds majority of which occur in the family Asteraceae. This could be due to the genetic makeup of the Asteraceae family.
The aqueous and ethanol extracts of $V$. amygdalina leaf displayed antibacterial activities on the bacterial isolates. This agrees with the report of Udochukwu et al. (2015) who reported that the aqueous and ethanol extracts of $V$. amygdalina possess antibacterial action against pure culture of clinical bacterial isolates. This observation could be due to the presence of phytocomponents in the $V$. amygdalina leaf extracts. The ethanol extract of $V$. amygdalina displayed a higher antibacterial activity against, Bacillus subtilis, Staphylococcus aureus, Streptococcus pyrogens, Enterococcus faecalis, Pseudomonas aeruginosa than the aqueous extract which had a higher antibacterial activity on Escherichia coli and Corynebacterium diphtheriae than the ethanol extract. This observation agrees with the study of Oboh and Enobhayisobo (2009) and Udochukwu et al. (2015) who observed inhibitory effect of the aqueous and ethanol extracts on the growth of Gram-positive bacterium, Staphylococcus aureus, and the Gram-negative bacterium, Escherichia coli. This observation may be attributed to the higher volatility of the ethanol which tends to extract more active compounds from the samples than water. A prior study by Ghamba et al. (2014) on the extracts of $V$. amygdalina leaves showed strong antimicrobial activities against tested isolates which agrees with recent study of Udochukwu et al. (2015) on the antimicrobial activities of $V$. amygdalina leaf extracts. The antimicrobial activity of $V$. amygdalina makes it a potential herb for drug development due to its inhibition effects on bacterial growth (Ghamba et al. 2014). Foo et al. (2014) suggested contradictory view on the effects of $V$. amygdalina extracts on E. coli strains though difference in susceptibility was said to be likely due to genetic diversity of the pathogen which gives rise to different resistant mechanisms (Noumedem et al. 2013).

The minimum inhibitory concentration (MIC) of $V$. amygdalina extracts on Escherichia coli, Bacillus subtilis, Staphylococcus aureus, Streptococcus pyogenes, Corynebacterium diphtheriae, Enterococcus faecalis and Pseudomonas aeruginosa. The MIC values obtained on the test organisms varied from one plant extract to the other; it could be observed that the MIC of ethanol extract for Bacillus subtilis, Staphylococcus aureus, Streptococcus pyrogens, Corynebacterium diphtheriae and Pseudomonas aeruginosa is $25 \mathrm{mg} / \mathrm{ml}$, while the MIC of ethanol extract for Enterococcus faecalis is $50 \mathrm{mg} / \mathrm{ml}$. The MIC values of the aqueous extract of $V$. amygdalina leaf show varying concentrations for the different isolates; the MIC values for Escherichia coli, Staphylococcus aureus, Enterococcus faecalis and Pseudomonas aeruginosa were observed to be $25 \mathrm{mg} / \mathrm{ml}$, while the MIC values for Bacillus substiles, Corynebacterium diphtheriae and Streptococcus pyrogens were 
observed to be $50 \mathrm{mg} / \mathrm{ml}$ for the aqueous extracts. This shows that $V$. amygdalina extracts have bacteriostatic effects on the isolates with the ethanol extract having more inhibitory effect on most of the isolates than the aqueous extract. This agrees with Ogundare et al. (2006), who showed that a similar plant species: $V$. tenoreana containing saponins, flavonoids, tannins and anthraquinones was found to have very potent antibacterial as well as antifungal activities. This may be because the ethanol extract has the ability to denature the protein of the microbial cell of the isolates, thereby destroying the cell wall/membrane of the bacterial isolates.

\section{Conclusions}

This study revealed the bioactive compounds present in $V$. amygdalina leaf; twenty to twenty-three bioactive compounds were identified in the aqueous and ethanol extracts of $V$. amygdalina which are mainly characterized by its percentage abundance. Hexadecanoic acid ethyl ester (24.37\%) and 1,1-diethoxy-3methylbutane (13.42\%) have the highest percentage (\%) abundance in aqueous and ethanol extract, respectively, while Cholest5-en-3-ol (3 $\beta$ )-, acetate and Isoamyl acetate have the least percentage abundance of $0.19 \%$ and $5.59 \%$ in aqueous and ethanol extract of $V$. amygdalina leaf, respectively. These bioactive compounds are known to demonstrate positive properties and capable of modulating metabolic processes and such as inhibition of receptor activities, antioxidant effect, inhibition or induction of enzymes, anti-inflammatory properties, inhibition of gene expression, and so on. The presence of these compounds in $V$. amygdalina leaf attests that the $V$. amygdalina leaf could potentiate the development of a new drug against diseases. At $25 \mathrm{mg} / \mathrm{ml}$, ethanol extract of $V$. amygdalina leaf was inhibitory against Bacillus subtilis, Staphylococcus aureus, Streptococcus pyrogens, Corynebacterium diphitheria and Pseudomonas aeruginosa. These findings indicate that the ethanol extract of $V$. amygdalina leaf can be employed in the treatment of water borne infections. Hexadecanoic acid ethyl ester could also be explored for conventional antibacterial studies. Research into the development of nutraceutical drugs from $V$. amygdalina should be encouraged based on nutraceutical and antimicrobial attributes. Researchers should also focus their investigation on the isolation and utilization of the bioactive components of this plant.

\section{Abbreviations}

GC-MS: Gas chromatography-mass spectroscopy; DMSO: Dimethylsulphoxide; DALYs: Disability-adjusted life years (DALYs); USA: United State of America; Qcs: Quality controls; Nacl: Sodium chloride.

\section{Acknowledgements}

The Department of Microbiology, School of Life Sciences, Federal University of Technology Akure, Akure Nigeria, is acknowledged for providing the basic infrastructure for carrying out the research work.

\section{Authors' contributions}

OBO conceived and designed the experiments, contributed to sample preparation, carried out the experiment, processed the experimental data, wrote the manuscript, designed the figures and contributed to the interpretation of the results. OO involved in planning, supervised the work and contributed to the interpretation of the results. TAl drafted the manuscript and performed the analysis and other substantial contributions. All authors discussed the results and commented on the manuscript. All authors read and approved the final manuscript.

Funding

Not applicable.

Availability of data and materials

The authors are willing to share all data used in this study upon a reasonable request to the corresponding author.

\section{Declarations}

Ethics approval and consent to participate

Not applicable.

\section{Consent for publication}

Not applicable.

Competing interest

The author declare that he has no competing interest.

Received: 1 October 2021 Accepted: 29 October 2021

Published online: 10 November 2021

\section{References}

Bwire G, Sack D, Kagirita A, Obala T, Debes K, Ram M, Komakech H, George C, Orach C (2020) The quality of drinking and domestic water from the surface water sources (lakes, rivers, irrigation canals and ponds) and springs in cholera prone communities of Uganda: an analysis of vital physicochemical parameters. BMC Public Health 20:1128

Corpuz M, Buonerba A, Vigliotta G, Zarra Y, Ballesteros F, Campiglia P, Belgiorno V, Korshin V, Naddeo V (2020) Viruses in wastewater: occurrence, abundance and detection methods. Sci Total Environ 745:140910

Etim KH, Ofor SE, Mandor UA, Ogar M (2012) Evaluation of the antibacterial potential of Vernonia amygdalina on foodborne pathogens isolated from kunu sold in Calabar. Niger J Microbiol Biotechnol Res 2:778-782

Fawole MO, Oso BA (2001) Laboratory manual of microbiology, Revised. Spectrum Books, Ibadan

Foo RQ, Manogaran E, Gabriel AA (2014) Antimicrobial and antioxidant studies of Vernonia Amygdalina. J Appl Pharm 6(4):360-371

Gashe F, Zeleke G (2017) Antimicrobial activities of Vernonia amygdalina Delile and Prunus africana extracts against multidrug resistant clinical strains. Res J Med Plants 11:142-147

Ghamba PE, Balla H, Goje LJ, Halidu A, Dauda MD (2014) In vitro antimicrobial activities of Vernonia amygdalina on selected clinical isolates. Int J Curr Microbiol Appl Sci 3(4):1103-1113

Gupta A, Sarker G, Rout A, Mondal T, Pal R (2015) Risk correlates of diarrhea in children under 5 years of age in slums of Bankura, West Bengal. J Global Infect Dis 7:23-29

Ibekwe VI, Nnanyere NF, Akujobi CO (2001) Studies on antibacterial activity and phytochemical qualities of extracts of orange peels. Int J Environ Health Hum Dev 2(1):41-46

Jenkins M, Ahmed S, Barnes A (2021) A systematic review of waterborne and water-related disease in animal populations of Florida from 1999-2019. PLOS ONE 16(7):e0255025 
Leboffe MJ, Michael BE (2014) Microbiology laboratory theory and application, 3rd edn. Morton Publishing Company, Englewood, p 105

Noumedem JA, Mihasan M, Kuiate JR, Stefan M, Cojocaru D, Dzoyem JP, Kuete $V(2013)$ In vitro antibacterial and antibiotic potentiation activities of four edible plants against multi drug resistant gram-negative species. BMC Complement Altern Med 13(1):190

Oboh FOJ, Enobhayisobo El (2009) Effect of aqueous extract of Vernonia amygdalina leaves on plasma lipids of hyperlipidemia adult male albino New Zealand rabbits. Afr Sci 10:4

Ogundare AO, Adetuyi FC, Akinyosoye FA (2006) Antimicrobial Activities of Vernonia tenoriana. Afr J Biotech 5(18):1663-1668

Okpasuo O, Aguzie F, Joy T, Okafor F (2020) Risk assessment of waterborne infections in Enugu State, Nigeria: implications of household water choices, knowledge, and practices. AIMS Public Health 7(3):634-649

Rai MK, Varma A, Pandey AK (2004) Antifungal potential of Spilanthescalva after inoculation of Piriformospor aindica (Das antimyzetische Potential von Spilanthescalvanachlnokulation von Piriformospor aindica). Mycoses 47:479-481

Tortora GJ, Funke BR, Case, Christine L (2016) Microbiology: an introductory, 11 th edn. Pearson Education Incorporation, Glenview

Udochukwu U, Omeje I, Uloma I, Oseiwe ID (2015) Phytochemical analysis of Vernonia amygdalina and Ocimum gratissimum extracts and their antibacterial activity on some drug resistant bacteria. Am J Resist Community 3(5):225-235

Vaou N, Stavropoulou E, Voidarou C, Tsigalou C, Bezirtzoglou E (2021) Towards advances in medicinal plant antimicrobial activity: a review study on challenges and future perspectives. Microorganisms 9:2041

Winn W, Allen S, Janda W, Koneman E, Procop G, Schreckenberger P, Woods G (2006) Koneman's colour atlas and textbook of diagnostic microbiology, 6th edn. Lippincott Williams and Wilkins, Philadephia

World Health Organization (2004) Assessment and monitoring of antimalarial drug efficacy for the treatment of uncomplicated falciparum malaria. World Health Organization, Geneva

World Health Organization (2019) Surveillance and outbreak management of water-related infectious diseases associated with water-supply Systems. WHO Regional Office for Europe UN City, Copenhagen $\varnothing$

\section{Publisher's Note}

Springer Nature remains neutral with regard to jurisdictional claims in published maps and institutional affiliations.

\section{Submit your manuscript to a SpringerOpen ${ }^{\circ}$ journal and benefit from:}

- Convenient online submission

- Rigorous peer review

- Open access: articles freely available online

- High visibility within the field

- Retaining the copyright to your article

Submit your next manuscript at $\boldsymbol{\sim}$ springeropen.com 